\title{
OVERLOAD OF MINIMUM STANDARDS FOR CO LLEGES OF EDUCATION AND STUDENTS'S PERFORMANCE IN NIGERIA CERTIFICATE IN EDUCATION EXAMINATION IN SOUTH-SOUTH, NIGERIA
}

\author{
DR. ISRAEL, PAUL CHIJIOKE \\ PSYCHOLOGY DEPARTMENT \\ FEDERAL COLLEGE OF EDUCATION \\ OBUDU \\ MRS. ISRAEL, HAPPINESS CHERECHI \\ CHRISTIAN RELIGIOUS STUDIES DEPARTMENT \\ FEDERAL COLLEGE OF EDUCATION \\ OBUDU
}

\author{
SPONSORD BY TETFUND \\ DOI: 10.31364/SCIRJ/v7.i12.2019.P1219735 \\ http://dx.doi.org/10.31364/SCIRJ/v7.i12.2019.P1219735
}

\begin{abstract}
This study was executed with a view to finding out the effect of the overload of the Minimum Standards Curriculum for Nigeria Certificate in Education (NCE) on students learning activities and on their performance in the Nigerian Certificate in
\end{abstract} Education (NCE) in the south-south geo-political zone of the country. Three research questions and three hypothesis were generated to guide the study. The data for the study were collected using documentary analysis and two questionnaires named "NCE Course Load Assessment Rating Scale (NCE CLARS) and Lecturers' Effectiveness Determinant Questionnaire (LEDQ)" administered to students and lecturers respectively. These questionnaires were constructed by the researchers and validated by experts in measurement and evaluation and curriculum studies respectively. The area of the study was the south- south geo-political zone of Nigeria. Five colleges of education were randomly selected (one from each state) out of a population of 11 federal and state colleges of education in the zone. Five hundred students and 250 lecturers were randomly drawn from the five colleges for the study. Student' final NCE results were equally collected randomly from the various departments in the five colleges and analysed for the purpose of comparing students' performance under different editions of the minimum standards. The data so collected were analysed using both descriptive and inferential statistics. The result of the analysis revealed inter alia that the overload of the NCCE minimum standard causes retardation in students' performance. Consequently, it was recommended among other things that the present move towards the 
revision of the current edition of the minimum standards should be intensified with a view to reducing the number of courses offered by student.

Key words: Curriculum, Overload, Minimum Standards, Performance.

\section{INTRODUCTION}

The Federal Government of Nigeria in 1989 established the National Commission for Colleges of education (NCCE). As a supervisory body in charge of Colleges of Education in the country. This is the reason why Borishade (2002) described this body as the third leg of the tripod of excellence in the supervision of tertiary education in Nigeria. The mandate given to the NCCE included laying down minimum standard for all programmes of teacher education and accrediting their certificates and other academic awards after obtaining thereof prior approval of the Minister (NCCE, 1990). This mandate was born out of the desire to achieve uniformity in practice and in standard among Colleges of Education (formerly called Advanced Teachers Colleges). The need for uniformity arose because the universities to which those colleges were affiliated employed confusing and discriminatory standards in matters of admission of NCE products into their B.Ed degree programmes.

Among the areas of teacher education programme that the NCCE focussed attention was the curriculum component. Its focus in this area was to determine the curriculum content which the student teachers will have to be exposed to and which will be considered adequate enough to enable them enter or re-enter the teaching profession with confidence in their ability to perform creditably as anticipated. Consequently, the NCCE produces the Minimum Standards for Nigerian Certificate in Education (NCE). This minimum standards is defined as the minimum the teacher educators should know and be able to do as well as their expected minimum dispositions towards their work if they must remain/progress in their career (NCCE, 2012).

Twenty eight years after the first edition of the minimum standards was published in 1990, it has undergone several revisions. Accompanying these revisions is either the introduction of new courses in the Minimum Standards or addition of more topics into the already existing courses. For example, whereas the first minimum standard published in 1990 contained 9 GSE courses; the third edition of minimum standard of 2002 contained 13 GSE courses, and the fifth (2012) edition contained 18 GSE courses. Similarly more topics have been added in the course outline of such already existing courses as Research Methods and Measurement and Evaluation.

The continuous increase in the number of courses and the expansion of the scope of other existing courses in the NCCE Minimum Standard has given rise to curriculum overload i.e. according to The National Council for Curriculum and Assessment (2010) a mismatch between capacity and load. Overloading the curriculum is a sure means of sacrificing quality in education at the 
altar of quantity. This overload of the minimum, standards could be responsible for the fall in the quality of products of teacher training institutions which Omalle (2010) observed when he said that the quality of teachers and their teaching skills was inadequate despite their qualification as university or college of education graduates. If at all curriculum overload can be tolerated at any level of education; it should not be at the level of teacher education because education at this level has a multiplier effect more than at any other level. This reasoning informed the former Minister of Education Professor Jibril Aminu (as cited in NCCE, 2002) when during NCCE's inauguration in 1989, he charged the commission to be fair but firm in all its dealings with the institutions, whether it be over funds or accreditation, or the establishment of new units. This he said was because we cannot compromise on accountability as poor quality in teacher education will be a national disaster, which we must avoid by insisting on only the best.

The absence of any known study dealing with the impact of the overload of the Minimum Standards Curriculum on NCE students' performance necessitates this investigation. The problem of this study therefore when posed in question form is: How does the overload of the minimum standards curriculum affect NCE students' learning activities and their performance in Nigeria Certificate in Education examination respectively?

The significance of this study lies in the fact that it will help the planners of the minimum standards curriculum to endeavour to strike a balance between available resources and curriculum content whenever they are reviewing the curriculum. Such a balance it is hoped will result in effective teaching, facilitation of learning and improvement in students' performance in examinations. Given the multiplier effect of teacher education, any improvement at this level of education will definitely result in an improvement in the quality of education at the primary and junior secondary school levels where the products of colleges of education are prepared to teach.

It was the purpose of this study to determine the effect of the overload of the NCCE minimum standards curriculum on students' learning and their performance in NCE examination.

In other to achieve this objective, the study sought answers to the following research questions:

1. How does the overload of the minimum standards affect Lecturers' effectiveness in teaching and assessment of students?

2. What is the effect of the over load of the curriculum on lecture timetable and on students' engagement in their academic activities?

3. How does the performance of students who did their NCE programme using different editions of the NCE minimum standards compare with one another?

The following hypotheses were also tested at $5 \%$ significance level:

$\mathrm{H}_{01 \text { : }}$ There is no significant difference $(\mathrm{P}<0.05)$ in GSE mean performance among students who graduated both prior to and with different editions of the NCCE minimum standards curriculum 
$\mathbf{H}_{\mathbf{0 2}}$ : There is no significant difference $(\mathrm{P}<0.05)$ in the mean performance in Education among students who graduated both prior to and with different editions of the NCCE minimum standards curriculum.

$\mathbf{H}_{\mathbf{0 3}}$. There is no significant difference $(\mathrm{P}<0.05)$ in the NCE overall mean performance among students who graduated both prior to and with different editions of the NCCE minimum standards curriculum.

\section{LITERATURE REVIEW}

When the learning which is planned for learners and guided by the school becomes too much as to hamper the effectiveness of teaching and learning, the curriculum could be said to have become overloaded. Eneogwe and Oguegbune-Okwuenu (2007) after a thorough examination of the meaning of curriculum content and the dictionary meaning of overload, went ahead to define curriculum content overload as excessive curriculum content which will affect both the learnability and the significance of the body of knowledge the learner will be exposed to. A more comprehensive definition of curriculum overload can be obtained by first of all considering the meaning of curriculum content. According to Hyattractions System (2016) curriculum content is the totality of what is to be taught in a school. These include the facts, principles and concepts. Curriculum overload therefore refers to a situation whereby the facts, principles and concepts that are taught in schools exceed the teaching capacity of the teachers or ability to absorb what is taught by the learners or the resources needed to deliver such content. This view of curriculum overload is sequel to the feasibility criterion of content selection which states that content should be learned within the time allowed, resources available, expertise of the teacher and nature of the learner (Ocampo, 2016). It could be deduced from this that when the time allowed to deliver the content of a given curriculum is not enough to do so, the curriculum could be described as overloaded. Also, when the available resources for delivering a given curriculum content are not sufficient to do so or the expertise of the teacher and nature of the learner make it difficult to deliver the entire curriculum content, the curriculum has become overloaded.

There is a direct relationship between curriculum overload and teacher overload. This is the reason why Erickson (as cited in Libit, 1995) described curriculum overload as a subset of teacher overload. What constitutes teacher overload is captured by Libit when he remarked that elementary school teachers are calling for the streamlining of the curriculum because they have too many competing objectives, directives, guides and tests, and not enough time for planning and teaching reading and science. It is evident from this remark that curriculum overload results when the curriculum contains too many activities that the teacher is not able to teach everything he is expected to teach within the available school hours. This view is consequent upon the National Council for Curriculum and Assessment's [(NCCA), 2010] definition of overload as a mismatch between capacity and load.

The NCCA further remarked that there is a sense from the literature, that overload is caused by important subjects competing for space with one another and also competing with what some consider to be less important subjects. Education reform has at times been 
blamed for curriculum overload. A onetime Nigerian Minister of Education by name Prof. Ruqayyatu, A. Rufai subscribes to this view by positing that the revision of the existing NCCE minimum standards in 2012 was something done in response to the transformation agenda of the then administration (NCCE, 2012).

Overloading of curriculum has been associated with some problems. For instance, Gove (as cited in Paton, 2010) noted that there has been loss of stability and purpose with new subjects and topics added more often in response to pressure groups than for sound pedagogical reasons. Curriculum overload also over tasks both teachers and their students. Thus, Campbell (2014) observes that by overloading the curriculum, we are increasing the demands on the curriculum and on the teachers and students to such a degree that either we fail to teach the basics and essentials in our schools or we offload lot of this to outside of the school time and that when the curriculum is overloaded, education is the first casualty. This observation, supports Libit's (1995) remark about what he calls a startling candid report presented to the Howard County School Board on overload which he says revealed that teachers feel overwhelmed by the numerous and confusing demands put on them by the central administration.

Abdul- Rahman (2009), has also reported that the Cabinet Committee towards the National Education Fundamentals in Malaysia has identified overloaded curriculum as resulting in lesson content being sometimes repeated and unrelated between subjects; that the subject syllabus contains too many items that makes the pupils burdened and bored; that teachers and pupils are always forced to finish the syllabus especially during examination period and that teaching and learning depends too much on textbooks. Another problem of overload noted by Abdul Rahman is the rush by teachers to cover the content which he said has altered the number of periods taught and has led to the introduction of cross-curricular areas. The effect of this he further pointed out was that the time consumed in a week is not enough for certain subjects and teachers have to make extra classes in the week-ends or after school just to finish the syllabus. He also pointed out that education in school has become examination oriented learning where classes in some subjects considered as minor have been neglected or sometimes replaced with examination subjects.

Eneogwe and Oguebgunne-Okwuenu (2007) described the overload of the NCE curriculum in Nigeria as being associated with serious frustrations. The problems they identified included teachers' failure to discharge competently their responsibilities as qualified teachers whereas their products are very poor quality NCE teachers in the country

Curriculum overload leads to poor performance by the learners. Obioma (as cited in Premium Times, 2014) attested to this fact by noting that curriculum overload could have been one of the major factors responsible for mass failures among students (at the secondary school level). Commenting on the new curriculum structure which reduces the number of subjects offered at the basic education level in Nigeria from 20 to 9 , he opined that with the new curriculum in place the Council (NERDC) expected to witness effective teaching and record better results at all levels. This means that overloaded curriculum not only results in poor performance by students but also makes teaching itself ineffective. 
Abdul Rahman (op. cit.) summarised the negative impact of curriculum overload on both teachers and student by noting that due to overloaded curriculum, the goals and aims of education will not be achieved as it will rather produce an unbalanced generation and society that will not learn the values from education and as a result, teachers will in the end be blamed by both parents and the society.

\section{METHODOLOGY}

This study adopted the descriptive survey design. The study was executed in the south-south geopolitical zone of Nigeria. The zone is made up of the following six states: Akwa Ibom, Bayelsa, Cross River, Delta, Edo, and River States. Each of these states has at least one approved college of education. On the whole, there are eleven approved federal and state colleges of education in the six states as at 2015 (Nicholas, 2015).

The research population comprised all the approved eleven colleges of education in the zone. The stratified random sampling was used to constitute a sample of five colleges of education. The stratification was done on state basis. The simple random sampling was used to draw one college of education from each state. However Bayelsa state was deliberately left out as the only college of education in that state was relatively newly established and as such cannot afford some of the required data.

The study was instrument triangulation. Thus, the following instruments were used for data collection: The NCE Course Load Assessment Rating Scale (NCE CLARS) administered to students, Lecturers' Effectiveness Determinant Questionnaire (LEDQ) administered to lecturers, and documentary analysis. The students' questionnaire was a researchers' constructed four-point rating scale. The lecturers' questionnaire was also constructed by the researchers and used to elicit relevant information from lecturers. Documentary analysis was also used to obtain records of students' performances within the period that each edition of the minimum standard lasted as well as prior to the introduction of the minimum standards. The research instruments were validated by experts in measurement and evaluation and in curriculum studies. A Crombach Alpha reliability index of 0.63 was computed for the rating scale. The data obtained with the above were analysed using simple percentage whereas the analysis of variance (ANOVA) was used to test the hypotheses. The various groups that the performances of their products were compared are:

1. The pre- minimum standards group i.e those who graduated prior to the introduction of minimum standards (1980-1992)

2. Those who graduated from 1992-1998 (products of first edition)

3. Those who graduated from 1999-2004 (products of second edition)

4. Those who graduated from 2005-2013 (products of 3rd and 4th editions)

5. Those who graduated from 2013 till 2018 (products of the 5th edition). 


\section{RESULTS}

The result of the study are presented in this section according to the research questions and hypotheses.

Research Question 1: How does the overload of the minimum standards affect Lecturers' effectiveness in teaching and assessment of students?

Table 1

Extent of Coverage of Course Content by Lecturers within the Allocated Time

OPTIONS NO PERCENTAGE (\%)

Teaches all the topics

$91 \quad 68.9$

Does not teach all topics

41

Total

Table 1 shows that while $68.9 \%$ of the lecturers cover their course content within the allotted time, the $31.1 \%$ do not cover all the topics in their course outline.

\section{Table 2}

\section{Lecturers' Self-Assessment of their Teaching Effectiveness}

$\begin{array}{lll}\text { Response } & \text { Number } & \text { Percentage (\%) } \\ \text { Effective } & 105 & 71.9\end{array}$

Not Effective $\quad 41 \quad 28.1$

$\underline{\text { Total }}$

$146 \quad 100$

Table 2 shows that 71.9 percent of the Lecturers rated themselves effective in their teaching and assessment of students in spite of their academic load whereas $28.1 \%$ rated themselves ineffective. This shows that lecturers' workload does not permit all of them to effectively execute their teaching responsibility.

Research Question 2: What is the effect of the overload of the curriculum on lecture timetable and on students' engagement in their academic activities?

Table 3

Impact of Curriculum Overload on Lecture time table and on Students' Engagement in their Academic Activities

\begin{tabular}{|lllllll|}
\hline$\underline{\text { S/N }}$ & $\underline{\text { Items }}$ & $\underline{N}$ & $\underline{\text { Mean }}$ & $\underline{\text { SD }^{*}}$ & $\underline{\text { Remark }}$ \\
\hline 1 & $\begin{array}{l}\text { The NCE curriculum is so crowded that we are meant to offer } \\
\text { more than } 12 \text { courses per semester }\end{array}$ & 500 & 3.64 & 0.75 & Accept \\
2 & $\begin{array}{l}\text { The time table is consequently overloaded } \\
\text { The following are the result of the overload: }\end{array}$ & 500 & 3.49 & 0.77 & Accept \\
& & & & & \\
\end{tabular}


3 We hardly have time for recreation and extra-curricular activities

$500 \quad 3.27 \quad 0.90 \quad$ Accept

4 Sometimes we start lecturers as early as 7.00 am and end at $6.00 \mathrm{pm}$

$500 \quad 3.24 \quad 1.04 \quad$ Accept

5 I find it difficult to complete the assignments given by lecturers due to lack of time

6 I find it difficult to attend all the lectures everyday

$\begin{array}{llll}500 & 3.04 & 1.01 & \text { Accept } \\ 493 & 2.95 & 1.06 & \text { Accept }\end{array}$

7 I feel so exhausted after lectures that I find it difficult to read at night

8 I do not have time to make use of the library

3.3

0.94 Accept

489

3.21

0.98 Accept

9 Students carrying over some courses do not have time to attend lectures in such courses

$\begin{array}{llll}500 & 3.47 \quad 0.87 \quad \text { Accept }\end{array}$

10 The examination time table is also so overcrowded that students carrying over some courses are meant to write two courses at a time

$500 \quad 3.43 \quad 0.91 \quad$ Accept

- $\quad \mathrm{SD}=$ Standard deviation

Table 3 shows that the students see their lecture time table as overcrowded. As a result of this, they have no time to do most of those things that make for effective learning and good performance as shown in the table.

Research Question 3: How do the performance of students who did their NCE programme under different editions of the NCCE minimum standards compare with one another?

In order to answer this question, the cumulative grade point average (CGPA) of students who did their NCE programme under different editions of the NCCE minimum standards are presented descriptively in table 4. The table shows their CGPAs in each of the three components of their programme namely: General Studies, Education, and their aggregate CGPA (a combination of General studies, Education and their subject(s) of specialization).

Table 4

Average CGPA of Students who Graduated under Different Editions of the Minimum Standards

\begin{tabular}{|c|c|c|c|c|c|c|c|c|c|}
\hline \multirow[b]{2}{*}{ Editions of Min. Stand. } & \multicolumn{3}{|c|}{ GEN.STUDIES } & \multicolumn{3}{|c|}{ EDUCATION } & \multicolumn{3}{|c|}{ AGGREGATE* } \\
\hline & $\mathrm{N}$ & $X$ & $\mathrm{~S}$ & $\mathrm{~N}$ & $X$ & $\mathrm{~S}$ & $\mathrm{~N}$ & $X$ & $\underline{S}$ \\
\hline Pre- M. S \# & 101 & 2.93 & 0.66 & 116 & 2.83 & 0.68 & 221 & 3.25 & 0.64 \\
\hline 1993-1998 & 240 & 2.82 & 0.65 & 240 & 3.13 & 0.54 & 240 & 3.2 & 0.51 \\
\hline $1999-2004$ & 240 & 2.65 & 0.65 & 240 & 3.05 & 0.52 & 240 & 3.21 & 0.50 \\
\hline
\end{tabular}




\begin{tabular}{lcccccccccc}
$2005-2013$ & 240 & 2.41 & 0.61 & 240 & & 2.70 & 0.50 & 240 & 3.07 & 0.56 \\
$2014-2018$ & 240 & 2.67 & 0.56 & 240 & 2.99 & 0.64 & 240 & 3.07 & 0.56 \\
\hline
\end{tabular}

Pre-M.S. \# = Pre-Minimum Standard; Aggregate* ${ }^{*}$ the average CGPA for General Studies, Education and Subject(s) of Specialization; $\mathrm{N}$ = sample size, $\mathrm{X}=$ mean; and $\mathrm{S}=$ standard deviation.

Table 4 shows that the highest CGPA of 2.93 in general studies was recorded before the introduction of the NCCE minimum standards (Pre- M.S) whereas the lowest (2.41) was recorded between 2005 and 2013. This was when the 3 rd and $4^{\text {th }}$ editions were in use. On the other hand, the highest CGPA of 3.13 in Education was recorded between 1993 and 1998 when students graduated under the $1^{\text {st }}$ edition of the NCCE minimum standards. Contrarily, the lowest overall CGPA of 2. 70 was also recorded between 2005 and 2013 when the $3^{\text {rd }}$ and $4^{\text {th }}$ editions were in operation. The table also shows that an aggregate highest CGPA of 3.26 was recorded under the first edition of the minimum standard whereas the lowest mean score of 3.07 was recorded when students graduated under the $3^{\text {rd, }} 4$ th and $5^{\text {th }}$ editions respectively.

Hypotheses 1: There is no significant difference $(\mathrm{P}<0.05)$ in the mean performance in GSE among students who graduated both prior to and with different editions of the NCCE minimum standards curriculum.

Table 5

Summary of Analysis of Variance of CGPA (in GSE) of Students who graduated Under Different Editions of the NCCE Minimum Standards Curriculum

\begin{tabular}{|c|c|c|c|c|c|}
\hline & Sum of Squares & df & Mean Square & $\mathrm{F}$ & Sig. \\
\hline $\begin{array}{l}\text { Between Groups } \\
\text { Within Groups Total }\end{array}$ & $\begin{array}{l}28.446 \\
409.477 \\
437.923\end{array}$ & $\begin{array}{l}41056 \\
1060\end{array}$ & $7.111 \quad .388$ & $18.340^{*}$ & .000 \\
\hline
\end{tabular}

- $\quad F$ is significant at 0.05

Table 5 shows that the groups that did their NCE programme before and with different editions of the NCCE minimum standards curriculum differ significantly in their GSE mean scores. The null hypothesis is therefore rejected at 0.05 level of significance.

In order to identify the particular groups with a significant mean difference, a Post Hoc test was carried out and the result shows that those who underwent their NCE programme before the introduction of the minimum standards performed significantly better in GSE than those who did their programmes under the $1^{\text {st }}, 2^{\text {nd }}, 3^{\text {rd }}, 4^{\text {th }}$, and $5^{\text {th }}$ editions respectively The Post Hoc Test also reveals that those who did their programme with the $1^{\text {st }}$ edition did better than those who did theirs with the $2^{\text {nd }}, 3^{\text {rd }}$, and 4 fourth editions respectively. However, graduates of the $5^{\text {th }}$ edition performed better than those of the $3^{\text {rd }}$ and $4^{\text {th }}$ editions. 
Hypotheses 2: There is no significant difference $(\mathrm{P}<0.05)$ in the mean performance in Education among students who graduated both prior to and with different editions of the NCCE minimum standards curriculum.

This hypothesis was tested using the analysis of variance statistics. The result of the analysis is shown in table 4.

Table 4

Summary of Analysis of Variance of CGPA in Education of Students who graduated Under Different Editions of the NCCE Minimum Standards Curriculum

\begin{tabular}{|c|c|c|c|c|c|c|}
\hline & & Sum of Squares & df & Mean Square & $\mathrm{F}$ & Sig. \\
\hline $\begin{array}{l}\text { Between } \\
\text { Within Groups }\end{array}$ & $\begin{array}{c}\text { Groups } \\
\text { Total }\end{array}$ & $\begin{array}{ll}27.073 & 331.039 \\
358.112 & \end{array}$ & $\begin{array}{l}4 \\
1071 \\
1075\end{array}$ & $\begin{array}{ll}6.768 & .309\end{array}$ & $21.897 *$ & .000 \\
\hline
\end{tabular}

- $\quad$ The mean difference is significant at 0.05 level

Table 4 shows that there are significant differences in Education CGPA at 0.05 level among the students who did their NCE programme before and with the different editions of the NCCE minimum standards curriculum. The null hypotheses is therefore rejected at this this level. The result a Post Hoc test revealed that those who did their NCE programme with the first edition of the minimum standards did significantly better in education than those whose programmes were based on the $3^{\text {rd }}, 4^{\text {th }}$, and $5^{\text {th }}$ editions respectively as well as the pre-minimum standards group. Also, products of the second edition of the minimum standards performed significantly better in education than the pre-minimum standards and the $3^{\text {rd }}$ and $4^{\text {th }}$ editions' groups respectively.

Hypotheses 3: $\quad$ There is no significant difference $(\mathrm{P}<0.05)$ in the NCE overall mean performance among students who graduated both prior to and with different editions of the NCCE minimum standards curriculum.

This hypotheses was tested using the analysis of variance statistics. The result of the analysis is shown in table 5 .

Table 5

Summary of Analysis of Variance of Overall NCE mean Performance of Students who graduated Under Different Editions of the NCCE Minimum Standards Curriculum

\begin{tabular}{|l|l|l|l|l|l|l|}
\hline & \multicolumn{2}{|l|}{ Sum of Squares } & Df & Mean Squares & F & Sig. \\
\hline Between Groups & $7.997 \quad 317.784$ & 4 & 1014 & 1.999 & $6.376^{*}$ & 0.000 \\
Within Groups Total & 325.781 & 1018 & & .313 & & \\
\hline
\end{tabular}

- $\quad$ The mean difference is significant at 0.05 level

Table 5 shows that there is a significant difference at $5 \%$ level among the overall NCE mean performance of students who did their NCE with different editions of the minimum standards as well as those who did theirs before the introduction of the minimum standards. We therefore reject the null hypothesis at this level of significance. A Post Hoc test shows that the pre minimum standards 
group performed significantly better than those of the $3^{\text {rd }}, 4^{\text {th }}$ and 5 th editions respectively. Similarly, products of the first edition performed significantly better than $3^{\text {rd }}, 4^{\text {th }}$, and $5^{\text {th }}$ editions respectively.

\section{SUMMARY OF RESULTS}

1. Lecturers' workload does not permit some of them to execute their teaching responsibilities effectively.

2. The students see their lecture time table as so much over crowded that it adversely affect their learning and participation in extracurricular activities.

3. Students who did their NCE programme before the introduction of the NCCE minimum standards curriculum did significantly better in general studies education than those who did their programmes under the various editions of the minimum standards.

4 .Products of the first edition of the minimum standards did significantly better in both education and their subjects of specialization than the products of the latter editions. They also outperformed the pre- minimum standards group in these areas.

\section{Discussion of Findings}

The first research question investigated the impact of Lecturers' workload on their teaching effectiveness. The finding in this respect was that whereas $68.9 \%$ cover their course content within the allotted time, $31.1 \%$ of the lecturers do not cover all the topics in their course outline. Also a greater percentage (72\%) of the lecturers see themselves as effective in discharging the duties whereas $28 \%$ rated themselves ineffective. These findings led to the conclusion that a good number of them do not teach exhaustively all the topics outlined in the course content due to insufficiency of time. This finding supports Ugoeze and Oguegbunne-Okwuenu (2007) who while commenting on the problems of curriculum overload submitted that it is true that student teachers eventually graduate in spite of those problems, yet it is certain that these teachers cannot competently discharge their responsibilities as qualified teachers.

It was also found that the lecture time table is so jam-packed with lectures that the students have no time to do all that is expected of learners for effective learning to take place and for students' recreation. Thus, almost all of the students agreed that the time table did not give them room to attend lectures regularly, complete all the assignments given, partake effectively in extracurricular activities, make use of the library, and read privately at night due to exhaustion after each day's lectures. Salisu (2004) made similar finding when he reported that lecture schedule (time table) affected students' attendance to lecture, as well as lead to absconding from lecture, and lateness to lecture. Worse still is the finding that examination timetable is also so compact that students who are carrying over some courses are meant to write examinations in such courses at the same time that they are writing examinations in other courses. This is a case of shortage of time of which Ojo (1998) equally reported when he said that sufficient time is not allocated to practical activities in physical and health education. 
The impact of the loadings of the various editions of the NCCE Minimum Standards Curriculum on students' performance was equally investigated. This was done by comparing students' performances in the various components of the curriculum namely: General Studies, Education, and their Aggregate performance which in addition to General Studies and Education included their subjects of specializations. The findings in this regard were that:

(a) Students who did their NCE programme before the introduction of the NCCE minimum standards curriculum did significantly better in general studies education than those who did their programmes under the various editions of the minimum standards. This finding is very significant considering the number of courses that constituted General studies prior to the introduction of the minimum standards. For instance, in the Federal College of Education Obudu, General Studies by then consisted of only two courses namely: General English 100 in year one and General English 200 in year two. Thus, limiting general studies component of the NCE curriculum to two courses enabled students perform better in this aspect of their curriculum.

(b) Products of the first edition of the minimum standards did significantly better in both Education and their subjects of specialization than the products of the latter editions. They also outperformed the pre- minimum standards group in these areas. A study of the various editions of the minimum standards reveals that the first edition contains 9 General Studies Education courses, and 19 Education courses unlike the 13 GSE and 24 Education courses contained in the $3^{\text {rd }}$ edition or the 18 GSE and 24 Education courses contained in the $5^{\text {th }}$ edition. In the area of subjects of specialization, it is seen that students combining biology and chemistry for example offered a total of 56 courses in both subjects under the first edition whereas such students have a total of 52 courses under the $5^{\text {th }}$ edition. This means that the $1^{\text {st }}$ edition provided for an in-depth study of one's subject of specialization than the fifth edition. (c) On the aggregate, a student offering biology and chemistry had a total number of 63 courses under the $1^{\text {st }}$ edition as against 94 courses under the $5^{\text {th }}$ editions due to many GSE and Education courses in the $5^{\text {th }}$ edition. This overload of the GSE and Education components of the curriculum is also the case with the $2^{\text {nd }}, 3^{\text {rd }}$ and $4^{\text {th }}$ editions. This must have accounted for Auna's (op.cit) submission that by the time the new curriculum is out, the students will have cause to smile as they will no longer be over burdened with irrelevant courses and that the failure rate among the students will be reduced.

\section{CONCLUSION}

The present edition of the NCCE Minimum Standards Curriculum for Colleges of Education in Nigeria is overloaded with too many courses. This overload is evident in terms of number of courses offered, effect of the lecture time table on students' performance of their learning activities and participation in extra-curricular activities, as well as Lecturers' effectiveness in their jobs. This overload of the curriculum content is especially seen in the area of General Studies and Education components of the curriculum. Such overload does not make room for effective study on the part of the students and has affected adversely students' performance especially in NCE examination. Such a poor performance must have equally contributed to the making of the post NCE degree 
programme a three years course as against the two years it used to be in times past. A little wonder why NCE holders of these days can hardly teach confidently in the junior secondary school whereas their pre-1990 counterparts taught senior secondary school classes confidently.

\section{Recommendations}

1. The current move to review the minimum standards should be vigorously pursued using the first edition of the Minimum standards as a yardstick.

2. The number of General Studies and Education courses currently offered by NCE students should be drastically reduced.

3. The current practice of assigning a credit load of one unit to courses should be changed and courses assigned a minimum of 2 credit units.

4 Time table planners should make provision for students' recreation and other personal academic work.

5. The level of education where products of the NCE programme are expected to teach should be taken into consideration while reviewing the minimum standards to avoid overloading the curriculum with irrelevant courses.

\section{REFERENCES}

Abdul Rahman, S. M. (2009). Overloaded curriculum and its effects to the teacher. From http://chekgumuna.blogspot.com/2011/08/

Borishade, A. B. (2002). Forward to national commission for colleges of education minimum standards for colleges of education ( $3^{\text {rd }}$ ed.) Kaduna : NCCE

Campbel,J. (2014). Overloaded curriculum may lead to underperformance. Retrieved from www.nst.com/news/2015/09/overloaded...

Eneogwe and Oguegbune-Okwuenu (2007).Curriculum content overload and teacher effectivenss: Focus on NCE curriculum. In Paul C. Israel and J. Oguegbune-Okwuenu (Eds.) Readings in Educational Foundations (pp.27-43). Obudu: Teo Ventures

Hyattractions System. (2016). Meaning of curriculum content and learning experience. From https://hyattractions.wordpress.com/2016/12/07/the-meaning-of-curriculum- content- and-learning-experiences/

Libit, H. (1995).Teachers attack curriculum overload. From http//articles.baltimoresun.com/ 1995-06-23/news/1995174036...

National Commission for Colleges of Education (1990). Minimum standards for NCE teachers' accreditation manual. Kaduna: Author

N.C.C.E. (2012). Nigeria certificate in education minimum standards for general education (2012 ed). Abuja: Author.

National Council for curriculum Assessment (2010). Curriculum overloads in primary schools: An overview of national and international experiences. USA: Author 
Nicholas, L. (2015). Complete list of approved colleges of education in Nigeria. From http://myedugist.com/approved-colleges-of-education-in-nigeria/

Ocampo,V. D. (2016). Curriculum content or subject matter. From https://www.slideshare.net/ vddeocampo/ curriculum-content-orsubject-matter

Ojo, O. (1998). An appraisal of the new NCCE curriculum for physical and health education in colleges of education in Nigeria. The Nigerian Teacher Today 6 (1) 154-161

Paton, G. (2010). Schools overloaded by curriculum reform, says exam chief. From www. Telegraph.co.uk/education/educationnews/8143429/schools-overloaded...

Premium Times. (2014). Education research council plans new curriculum for schools. From https://www.premiumtimesng.com/news/5025-education_research_council_plans_new_curriculum_for_schools.html

Salisu, A. R. (2004). Effects of lecturer schedules on students' academic performance. The Nigerian Teacher Today 12, (1) 81-85 